\title{
STUDI PELAKSANAAN STANDAR PROSES DI SEKOLAH MENENGAH KEJURUAN
}

\author{
Astrada $^{1}$, Amay Suherman ${ }^{2}$, Yayat $^{3}$ \\ DepartemenPendidikan Teknik Mesin, FPTK UPI \\ Jl. Dr. Setiabudhi No. 207 Bandung 40154 \\ astradadedek@rocketmail.com
}

\begin{abstract}
ABSTRAK
Tujuan dari penelitian ini adalah untuk memperoleh gambaran nyata tentang penyusunan rencana proses pembelajaran berdasarkan standar proses, pelaksanaan pembelajaran, dan evaluasi pembelajaran. Metode yang digunakan dalam penelitian ini yaitu metode deskriptif. Hasil penelitian menunjukan bahwa: 1) kelengkapan RPP yang dibuat oleh guru mata pelajaran produktif hanya mencapai 73,74\%; 2) keterlaksanaan proses belajar mengajar berdasarkan RPP yang telah dikembangkan baru mencapai 72\%; 3) keterlaksanaan evaluasi pembelajaran berdasarkan RPP yang telah dikembangkan mencapai 42\%. Berdasarkan hasil penelitian, disimpulkan bahwa pelaksanaan standar proses di SMKN 1 Ngabangyang meliputi perencanaan pembelajaran, pelaksanaan pembelajaran, dan evaluasi pembelajaran belum sesuai dengan tuntutan BSNP.
\end{abstract}

Kata kunci: standar proses, RPP, evaluasi belajar.

\section{PENDAHULUAN}

Standar pendidik merupakan standar yang telah ditetapkan oleh BSNP untuk melaksanakan kegiatan pembelajaran. Standar tersebut ditentukan untuk menjaga dan meningkatkan kualitas pendidikan atau output hasil pendidikan yang berkualitas. Seorang guru/pendidik untuk SMK/MAK harus mempunyai kualifikasi akademik, mempunyai program keahlian yang sesuai dengan mata pelajaran yang diajarkan, dan harus memiliki sertifikasi profesi guru. Seperti yang telah ditetapkan oleh BSNP tentang standar tenaga pendidik yaitu: kualifikasi akademik pendidikan minimum diploma empat (D-IV) atau sarjana (SI), latar belakang pendidikan tinggi dengan program pendidikan yang sesuai dengan mata pelajaran yang diajarkan dan sertifikasi profesi guru untuk SMK/MAK.

Standar pendidik memiliki tujuan seperti yang telah ditetapkan oleh BSNP. Tujuan dari standar pendidik yang telah ditetapkan adalah agar meningkatkan kecerdasan, pengetahuan, kepribadian, akhlak mulia, serta keterampilan seseorang untuk hidup mandiri dan mengikuti pendidikan lebih lanjut sesuai dengan kejuruannya dan meningkatkan kualitas mutu pendidikan di Indonesia.

\footnotetext{
${ }^{1}$ Mahasiswa Departemen Pendidikan Teknik Mesin FPTK UPI

${ }^{2}$ Dosen Departemen Pendidikan Teknik Mesin FPTK UPI

${ }^{3}$ Dosen Departemen Pendidikan Teknik Mesin FPTK UPI
} 
Pendidik pada program keahlian Teknik Kendaraan Ringan (TKR) di SMKN1 Ngabang tenaga pendidiknya sebanyak lima guru yang seluruhnya merupakan guru honorer. Guru-guru tersebut terdiri dari satu guru memiliki bidang keahlian permesinan dengan jenjang pendidikan SI, satu guru memiliki bidang keahlian otomotif dengan jenjang pendidikan D3, satu guru dengan jenjang pendidikan lulusan SMK yang memiliki kealian dalam bidang otomotif dan sudah berpengalaman dalam bidang otomotif karena sudah lama bekerja pada perusahaan otomotif di bagian teknik (teknisi). Dua guru memiliki bidang keahlian otomotif dengan jenjang pendidikan SI.

Berdasarkan jumlah guru sebanyak lima orang dan dengan bidang keahlian yang dimiliki oleh guru sebagian besar belum sesuai dengan program keahlian yang ada di SMKN 1 Terpadu Ngabang. Khususnya program keahlian TKR, terdapat kesenjangan antara jumlah tenaga pendidik dan bidang keahlian dengan tuntutan standar tenaga pendidik yang telah ditetapkan oleh BSNP. Kesenjangan tersebut akan menimbulkan dampak yang kurang baik terhadap terlaksananya standar proses. Merujuk dari latar belakang di atas, peneliti berkeinginan untuk melakukan penelitian dengan melihat sejauh mana ketercapaian pelaksanaan standar proses di SMKN 1 Ngabang berdasarkan tuntutan BSNP. Tujuan dari penelitian ini yaitu untuk mendeskripsikan dan menggambarkan keberhasilan standar nasional pendidikan dari aspek standar proses.

Menurut PP Nomor 19 Tahun 2005, pasal 1 butir 6: Standar proses adalah Standar Nasional Pendidikan yang berkaitan dengan pelaksanaan pembelajaran pada satuan pendidikan untuk mencapai standar kompetensi lulusan. Standar proses untuk satuan pendidikan dasar dan menengah mencakup perencanaan proses pembelajaran, pelaksanaan proses pembelajaran, pelaksanaan hasil pembelajaran dan pengawasan proses pembelajaran.

Perencanaan pembelajaran merupakan upaya untuk mencapai suatu yang akan dilaksanakan sesuai dengan apa yang direncanakan, tepat waktu, dan dapat dikontrol saat pelaksanaannya. Perencanaan dapat menolong pencapaian suatu sasaran lebih ekonomis, tepat waktu dan memberi peluang untuk lebih mudah dikontrol dan dimonitor dalam pelaksanaannya. Perencanaan proses pembelajaran adalah kegiatan yang harus dilakukan sebelum pelaksanaan proses pembelajaran dilakukan, (Harjanto, 2000).

Pelaksanaan pembelajaran merupakan implementasi dari RPP. Pelaksanaan pembelajaran meliputi kegiatan pendahuluan, kegiatan inti, dan kegiatan penutup. Kegiatan pendahuluan 
merupakan kegiatan yang dilakukan sebelum masuk pada kegiatan yang sebenarnya, yaitu kegiatan inti. Kegiatan yang dilakukan oleh guru untuk menciptakan suasana siap mental dan menimbulkan perhatian siswa agar terpusat pada hal-hal yang akan dipelajari, (Abimanyu, 1984). Kegiatan inti merupakan proses kegiatan belajar mengajar di mana guru harus mencapai tujuan pembelajaran dengan tepat sesuai dengan yang telah direncanakan. Belajar merupakan proses perubahan sikap dan tingkah laku setelah terjadinya interaksi dengan sumber belajar. Sumber belajar dapat berupa buku, lingkungan, guru, atau sesama teman. Tujuan mengajar bertitik tolak dari perubahan tingkah laku siswa, (Hamalik, 2013). Dalam hal ini guru harus bisa menyampaikan suatu materi dan dapat diterima oleh siswa baik dalam ranah afektif, kognitif, maupun psikomotorik. Usaha menutup palajaran dimaksudkan untuk memberi gambaran menyeluruh tentang apa yang telah dipelajari siswa, mengetahui tingkat pencapaian siswa dan tingkat keberhasilan guru dalam proses belajar mengajar, (Abimanyu, 1984). Berdasarkan pernyataan di atas dapat disimpulkan bahwa kegiatan penutup merupakan kegiatan yang dilakukan guru untuk mengakhiri kegiatan inti pelajaran.

Penilaian merupakan alat ukur yang dilakukan oleh seseorang untuk melihat apakah sesuatu yang dilakukan sudah sesuai dengan yang diharapkan. Evaluasi merupakan sebuah proses pengumpulan data untuk menentukan sejauh mana, dalam hal apa, dan bagaimana tujuan pendidikan sudah tercapai, (Arikunto, 2013). Khususnya pada dunia pendidikan, penilaian dilakukan oleh guru terhadap hasil pembelajaran untuk mengukur tingkat pencapaian kompetensi peserta didik, serta digunakan sebagai bahan penyusunan laporan kemajuan hasil belajar, dan memperbaiki proses pembelajaran.

\section{METODE PENELITIAN}

Lokasi pengambilan data dilaksanakan di SMKN 1 Terpadu Ngabang Kabupaten Landak (Kalimantan Barat). Populasi atau wilayah data yang menjadi subjek dalam penelitian ini yaitu guru mata pelajaran produktif di SMKN 1 Ngabang yang berjumlah lima orang. Adapun yang menjadi sampel dalam penelitian ini yaitu guru mata pelajaran produktif yang menyusun RPP untuk proses belajar mengajar. Sampel yang diteliti sebanyak tiga orang.

Metode penelitian yang digunakan terkait dengan judul ini yaitu metode penelitian deskriptif dengan pendekatan kuantitatif, menggunakan pendekatan kuantitatif karena dalam penelitian menggunakan angka persentase terkait dengan tingkat ketercapaian penyusunan RPP, 
keterlaksanaan pelaksanaan pembelajaran, dan keterlaksanaan evaluasi pembelajaran. Metode ini merupakan metode yang efektif untuk tujuan mendeskripsikan atau menggambarkan fenomena yang ada, baik fenomena yang bersifat alamiah maupun fenomena hasil rekayasa. Mengingat pentingnya objektivitas dan keutuhan yang harus dikumpulkan, maka peneliti menggunakan alat atau instrumen data di lapangan berupa pedoman wawancara, pedoman dokumentasi, dan pedoman observasi sebagai alat untuk mendapatkan data hasil penelitian. Teknik pengumpulan data dalam penelitian ini yaitu menggunakan teknik wawancara, dokumentasi, dan observasi. Pengolahan data digunakan rumus persentase. Penggunaan rumus persentase bertujuan untuk melihat ketercapaian pelaksanaan standar proses dengan berpedoman pada BSNP.

\section{HASIL PENELITIAN}

Data yang diamati terkait dengan pelaksanaan standar proses yaitu rencana pelaksanaan pembelajaran, pelaksanaan pembelajaran, dan evaluasi pembelajaran. Pelaksanaan standar proses di SMKN1 Terpadu Ngabang secara garis besar sudah terlaksana, akan tetapi masih banyak kekurangan dalam pelaksanaannya. Persentase ketercapaian (Gambar 1) pelaksanaan standar proses di SMKN1 Terpadu Ngabang.

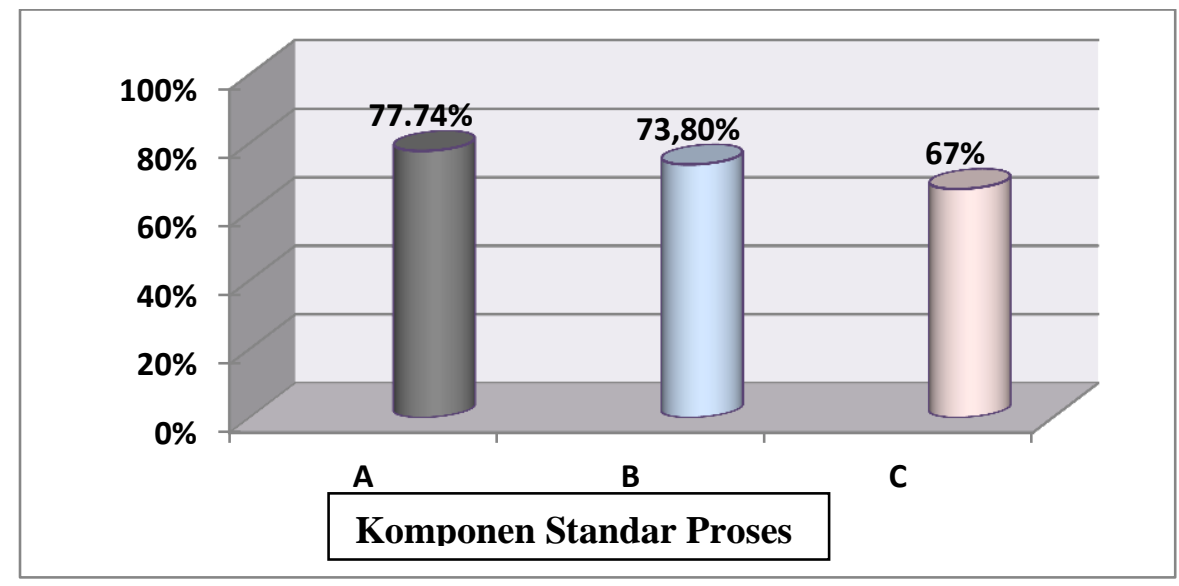

Gambar 1. Ketercapaian Standar Proses di SMKN1 Terpadu Ngabang.

A. Rencana Pelaksanaan Pembelajaran (RPP), B. Pelaksanaan Pembelajaran, C. Evaluasi Pembelajaran.

Adapun data mengenai hasil penelitian ketiga responden tentang kelengkapan RPP mata pelajaran produktif di SMKN1 Terpadu Ngabang dapat dilihat pada diagram batang di bawah ini. 


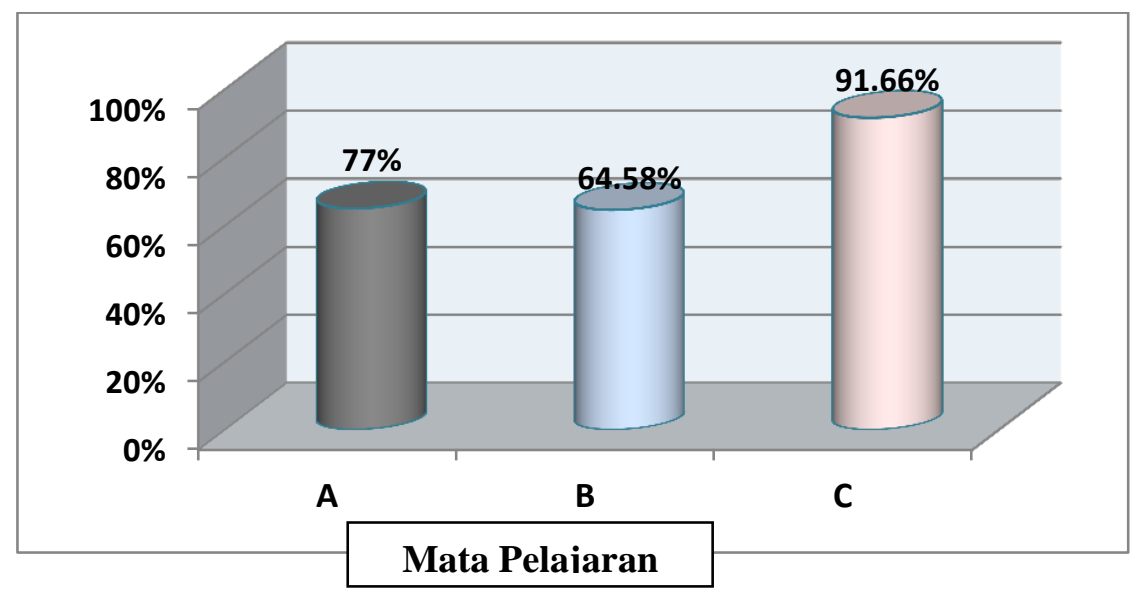

Gambar 2. Diagram Tingkat Kelengkapan RPP Mata Pelajaran Produktif.

A. Memperbaiki Unit Kopling \& Komponen Sistem Pengoperasiannya, B. Melakukan Perbaikan Sistem Hidrolik, C. Penggunaan dan Pemeliharaan Alat Ukur.

Tingkat kelengkapan RPP (Gambar 2)pada mata pelajaran memperbaiki unit kopling dan komponen-komponen sistem pengoprasiannya sebesar 77\%, melakukan perbaikan sistem hidrolik sebesar 64,58\%, penggunaan dan pemeliharaan alat ukur sebesar 91,66\%. Hasil penelitian menunjukkan pelaksanaan pembelajaran di SMKN 1 Terpadu Ngabang khususnya program keahlian TKR lebih dari setengahnya telah terlaksana. Tingkat ketercapaian pelaksanaan pembelajaran (Gambar 3) yang dilakukan oleh guru mata pelajaran produktif sebesar 73,78\%. Berdasarkan penelitian dengan mengamati secara langsung tentang pelaksanaan pembelajaran, maka peneliti mendapatkan data-data tentang pelaksanaan pembelajaran berdasarkan RPP.

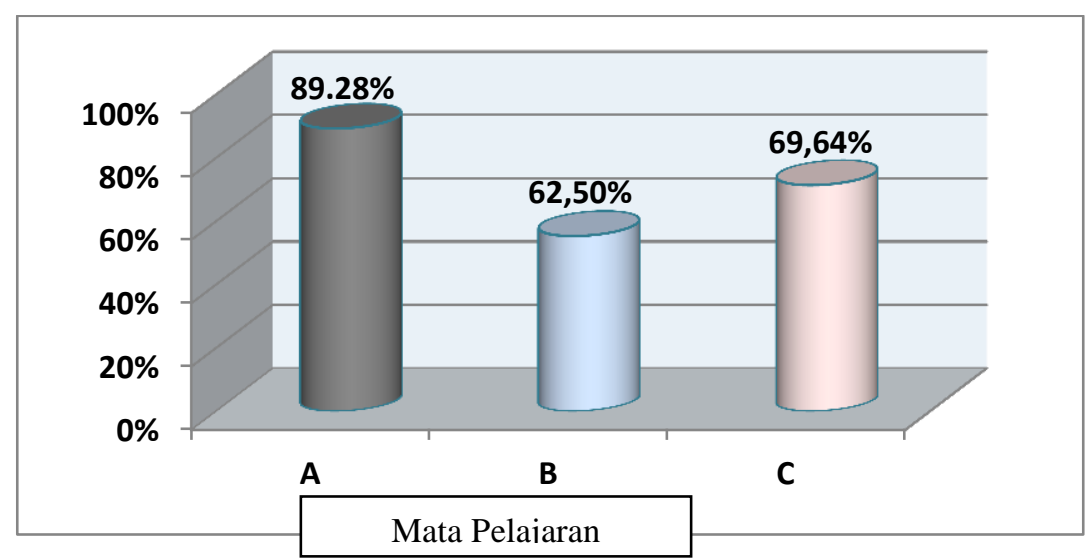

Gambar 3. Persentase Ketercapaian Pelaksanaaan Pembelajaran.

A. Memperbaiki Unit Kopling \&Komponen Sistem Pengoperasiannya, B. Melakukan Perbaikan Sistem Hidrolik, C. Penggunaan dan Pemeliharaan Alat Ukur. 
Hasil penelitian, pelaksanaan penilaian hasil belajar/evaluasi pembelajaran belum sepenuhnya dilaksanakan oleh guru-guru di SMKN 1 Terpadu Ngabang khususnya program keahlian teknik kendaraan ringan. Tingkat keterlaksanaan evaluasi pembelajaran (Gambar 4) berdasarkan evaluasi yang telah dirancang dalam RPP sebesar 67\%. Hal ini menunjukan tingkat keterlaksanaan evaluasi pembelajaran oleh responden lebih dari setengahnya telah terlaksana.

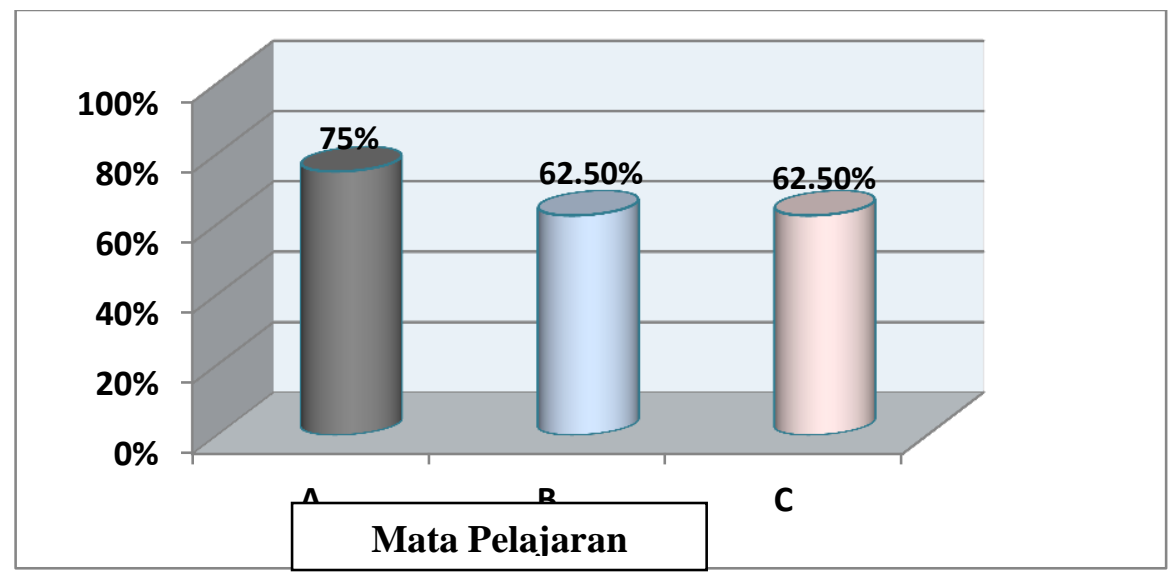

Gambar 4. Ketercapaian Penilaian Hasil Belajar/Evaluasi.

A. Memperbaiki Unit Kopling \&Komponen Sistem Pengoperasiannya. B. Melakukan Perbaikan Sistem Hidrolik. C. Penggunaan dan Pemeliharaan Alat Ukur.

\section{PEMBAHASAN}

Hasil penelitian menunjukan bahwa, ternyata proses penyusunan RPP belum dilaksanakan dengan optimal oleh sebagian besar guru mata pelajaran produktif di SMKN 1 Terpadu Ngabang. Hal ini akan mempersulit guru yang bersangkutan dalam mencapai tujuan pembelajaran yang sesuai dengan standar kompetensi lulusan. Dampak yang lain juga akan timbul, yaitu kompetensi keahlian siswa tidak akan tercapai sesuai dengan waktu yang telah ditetapkan. Dalam mencapai tujuan pembelajaran, guru harus merancang perencanaan pembelajaran agar proses pembelajaran terstruktur dan materi pembelajaran dapat tercapai sesuai dengan kompetensi yang telah dirancang berdasarkan standar kompetensi lulusan. Hal ini sejalan dengan pendapat Sagala (2005:136) yaitu: perencanaan pembelajaran diartikan sebagai proses penyusunan materi pelajaran, penggunaan media pembelajaran, penggunaan pendekatan atau metode pembelajaran, dalam suatu alokasi waktu yang akan dilaksanakan pada masa satu semester yang akan datang untuk pencapai tujuan yang akan didapatnya selama mengikuti kegiatan pembelajaran. 
Fungsi RPP dalam pelaksanaan pembelajaran sangatlah penting. Hal ini dikarenakan RPP merupakan pedoman bagi guru dalam mencapai kompetensi dalam KBM. RPP dalam pembelajaran dapat berfungsi sebagai perencanaan dan pelaksanaan. Fungsi RPP dalam perencanaan yaitu untuk mendorong guru agar lebih siap melakukan kegiatan pembelajaran dengan perencanaan yang matang, sedangkan dalam pelaksanaan, perencanaan berfungsi untuk mengefektifkan proses pembelajaran sesuai dengan apa yang direncanakan.

Kedua fungsi tersebut sesuai dengan fungsi RPP yang tertuang dalam KTSP yaitu RPP hendaknya dapat mendorong guru lebih siap melakukan kegiatan pembelajaran dengan perencanaan yang matang. Setiap akan melakukan pembelajaran guru wajib memiliki persiapan, baik persiapan tertulis maupun tidak tertulis. Tanpa persiapan maka kompetensi akan sulit tercapai. Pelaksanaan perencanaan RPP berfungsi untuk mengefektifkan proses pembelajaran sesuai dengan apa yang direncanakan. Materi standar yang dikembangkan dan dijadikan bahan kajian oleh peserta didik harus disesuaikan dengan kebutuhan dan kemampuannya, mengandung nilai fungsional, praktis, serta disesuaikan dengan kondisi dan kebutuhan lingkungan, sekolah, dan daerah. Oleh karena itu, kegiatan pembelajaran harus terorganisasi melalui serangkaian kegiatan tertentu, dengan strategi yang tepat dan mumpuni.

Kemampuan guru dalam membuka pelajaran hampir seluruhnya telah dilaksanakan oleh guru-guru produktif TKR di SMKN 1 Terpadu Ngabang. Akan tetapi, ada guru yang belum sepenuhnya menguasai dalam kemampuan membuka pelajaran. Berdasarkan hasil observasi peneliti mendapatkan ada sebagian guru dalam membuka pelajaran hanya berdoa, mengabsen siswa, dan langsung masuk ke kegiatan inti. Kegiatan pendahuluan harus dilakukan oleh seorang pendidik sebelum masuk pada kegiatan inti. Kegiatan ini bertujuan untuk mengarahkan minat dan menyiapkan mental peserta didik agar dapat fokus dalam kegiatan belajar mengajar.

Hal ini sejalan dengan pendapat Abimanyu (1984:2) yang mengatakan membuka pelajaran adalah kegiatan yang dilakukan oleh guru untuk menciptakan suasana siap mental dan menimbulkan perhatian siswa agar terpusat pada hal-hal yang akan dipelajari. Pernyataan yang hampir sama juga dikemukakan oleh Paranto (1985:19) yaitu siasat membuka pelajaran adalah usaha yang dilakukan oleh guru untuk menciptakan pra kondisi bagi murid agar mental maupun perhatian terpusat pada apa yang akan dipelajari sehingga usaha tersebut akan memberi efek positif terhadap kegiatan belajar. Seorang pendidik harus mampu menguasai kemampuan dalam membuka pelajaran. Seperti yang terdapat pada buku panduan PLP UPI 2012, kemampuan dalam 
membuka pelajaran terdiri dari: menarik perhatian siswa, memotivasi siswa, memuat kaitan materi ajar sebelumnya dengan materi ajar yang akan disampaikan, dan memberi acuan materi ajar yang akan disampaikan.

Dampak yang akan timbul jika guru tidak melaksanakan kegiatan pendahuluan yang optimal yaitu, siswa tidak akan fokus dalam menerima materi pelajaran dan akan mengakibatkan susahnya dalam mencapai kompetensi keahlian. Kemampuan membuka pelajaran harus dimiliki oleh setiap guru. Oleh karena itu, guru harus terus mengasah kemampuannya dalam membuka pelajaran. Kegiatan inti merupakan kegiatan dimana guru memberikan materi ajar kepada siswa. Kegiatan inti yang dilaksanakan oleh guru-guru produktif di SMKN 1 Terpadu Ngabang sudah cukup baik. Hal ini terlihat dari materi ajar yang telah disampaikan oleh guru-guru tersebut sudah sesuai dengan indikator pencapaian kompetensi yang terdapat pada RPP. Pengamatan juga dilakukan pada sikap guru dalam proses pembelajaran, implementasi langkah-langkah pembelajaran, penggunaan media pembelajaran.

Secara umum, sikap guru dalam proses pembelajaran sudah cukup baik, meskipun saat penelitian masih ada guru yang mengoperasikan telpon genggam saat proses KBM berlangsung. Implementasi langkah-langkah pembelajaran merupakan pelaksanaan skenario yang dibuat dalam RPP. Ketiga guru hampir rata-rata melaksanakan skenario pembelajaran tidak sesuai dengan waktu dan bentuk yang dirancang. Hal ini akan mengakibatkan belum tercapainya kompetensi keahlian dengan tepat waktu. Media untuk menunjang pembelajaran di SMKN 1 Terpadu Ngabang masih sangat minim. Meskipun demikian, guru telah berupaya menggunakan media pembelajaran semaksimal mungkin agar pesan dalam pembelajaran dapat tercapai dengan maksimal.

Kemampuan menutup pelajaran merupakan kegiatan akhir dari proses pembelajaran. Aspek-aspek yang terdapat pada kegiatan penutup yang ada pada panduan PLP UPI 2012 meliputi: meninjau kembali/menyimpulkan materi kompetensi yang diajarkan, memberi kesempatan bertanya, menugaskan ko-kurikuler, dan menginformasikan materi ajar berikutnya sudah tergolong cukup. Dalam pelaksanaannya, ada beberapa aspek yang kurang diperhatikan guru dalam menutup pelajaran. Permasalahan yang didapat yaitu, kadang-kadang responden dalam pelaksanaan pembelajaran tidak sesuai dengan RPP yang telah disusun. Ada sebagian guru yang tidak memberi kesempatan bertanya kepada siswa dikarenakan waktu tidak mencukupi untuk melakukan tanya jawab. 
Kesalahan juga dilakukan yaitu terkait dengan alokasi waktu yang telah ditetapkan. Hal ini dikarenakan materi yang diajarkan belum tercapai dan pengaturan alokasi waktu yang kurang optimal oleh guru yang bersangkutan. Hal ini akan mempersulit guru dalam mencapai tujuan dalam kegiatan menutup pelajaran. Kegiatan penutup merupakan kegiatan yang dilakukan oleh guru untuk mengakhiri kegiatan inti. Tujuan dari kegiatan menutup pelajaran yaitu untuk mengulas secara singkat/merangkum kegiatan yang telah dilakukan dan mengukur sampai di mana tingkat ketercapaian peserta didik dalam proses belajar mengajar. Usaha menutup palajaran dimaksudkan untuk memberi Gambaran menyeluruh tentang apa yang telah dipelajari siswa, mengetahui tingkat pencapaian siswa dan tingkat keberhasilan guru dalam proses belajar mengajar (Abimanyu,1984).

Pelaksanaan evaluasi pembelajaran di SMKN 1 Terpadu Ngabang belum optimal. Pelaksanaan evaluasi yang telah dilaksanakan oleh guru-guru produktif di SMKN 1 Terpadu Ngabang mencapai 67\%. Artinya, pelaksanaan evaluasi pembelajaran lebih dari setengahnya telah dilaksanakan sesuai dengan RPP yang telah disusun oleh guru yang bersangkutan. Berdasarkan rambu-rambu penelitian seperti yang terdapat pada buku panduan PLP UPI 2012 yaitu: melakukan evaluasi berdasarkan tuntutan aspek kompetensi, melakukan evaluasi sesuai dengan butir soal yang telah direncanakan dalam RPP, melakukan evaluasi sesuai dengan alokasi waktu yang direncanakan, melakukan evaluasi sesuai dengan bentuk dan jenis yang dirancang. Ternyata pada pelaksanaan evaluasi pembelajaran ada beberapa masalah yang terdapat yaitu, ada responden yang tidak mencantumkan evaluasi pembelajaran dalam RPP.

Adapun pencantuman evaluasi pada RPP tidak sesuai dengan indikator pencapaian kompetensi, dengan tidak sesuainya evaluasi dengan indikator pencapaian kompetensi, maka akan mengakibatkan susahnya mengukur tingkat ketercapaian kompetensi terhadap siswa. Kekurangan dalam evaluasi juga terdapat pada kurangnya perhatian guru dalam mengukur tingkat ketercapaian kompetensi, jadi evaluasi pembelajaran biasanya dilakukan apabila akan menjelang UTS dan UAS saja. Berdasarkan pengamatan dilapangan sebagian besar guru belum melaksanakan evaluasi pembelajaran dengan baik.

Tujuan penilaian hasil belajar pada dasarnya adalah untuk mengetahui seberapa besar ketercapaian penguasaan, kemampuan, dan kemajuan hasil belajar dari materi yang telah diberikan kepada siswa. Tujuan penilaian hasil belajar yaitu: untuk mengetahui tingkat 
penguasaan peserta didik terhadap materi yang telah diberikan; untuk mengetahui kecakapan, motivasi, bakat, minat, dan sikap peserta didik terhadap program pembelajaran, (Arifin, 2012).

Untuk mengetahui tingkat kemajuan dan kesesuaian hasil belajar peserta didik dengan standar kompetensi dan kompetensi dasar yang telah ditetapkan; untuk mendiagnosis keunggulan dan kelemahan peserta didik dalam mengikuti kegiatan pembelajaran. Keunggulan peserta didik dapat dijadikan dasar bagi guru untuk memberikan pembinaan dan pengembangan lebih lanjut, sedangkan kelemahannya dapat dijadikan acuan untuk memberikan bantuan atau bimbingan; untuk seleksi, yaitu memilih dan menentukan peserta didik yang sesuai dengan jenis pendidikan tertentu; untuk menentukan kenaikan kelas; untuk menempatkan peserta didik sesuai dengan potensi yang dimilikinya.

\section{KESIMPULAN}

Kesimpulan yang dapat diungkapkan oleh peneliti adalah dalam menyusun RPP, guru belum sepenuhnya mengacu pada ketentuan yang disyaratkan oleh BSNP. Pelaksanaan pembelajaran pada mata pelajaran produktif yang dilaksanakan oleh guru produktif di SMKN 1 Terpadu Ngabang belum sepenuhnya mengacu pada RPP yang telah disusun. Evaluasi pembelajaran yang dirancang dan dilaksanakan oleh guru-guru produktif khususnya pada mata pelajaran produktif di SMKN 1 Terpadu Ngabang belum sepenuhnya tercapai, yaitu kurang dari setengahnya telah dilaksanakan.

\section{DAFTAR PUSTAKA}

Abimanyu, S. (1984). Keterampilan Membuka dan Menutup Pelajaran. Jakarta: Bumi Aksara.

Arifin, Z. (2012). Evaluasi Pembelajaran. Bandung: PT. Remaja Rosdakarya.

Arikunto, S. (2013). Dasar-Dasar Evaluasi Pendidikan. Jakarta: Bumi Aksara.

Hamalik, O. (2013). Proses Belajar Mengajar. Jakarta: Bumi Aksara.

Harjanto. (2000). Perencanaan Pengajaran. Jakarta: Rineka Cipta.

Paranto, S. et al. (1985). Pengajaran Mikro. Jakarta: Raja Grafindo.

Sagala, S. (2005). Konsep dan Makna Pembelajaran. Badung: Alfabeta. 